\title{
Missbruk bland ungdomar på särskilda ungdomshem - ADAD som verktyg för bedömning och behandling
}

\author{
NINIVE VON GREIFF
}

Avsikten med studien är att jämföra olika bedömningar av förekomst och omfattning av missbruk bland ungdomar somplaceras på särskilt ungdomshem. Studiens material är hämtat ur data från ADAD (Adolescent Drug Abuse Diagnosis) åren 1997-2001. Resultaten, som visar på stora skillnader mellan olika bedömningar av missbruk, diskuteras med utgångspunkt i problembeskrivningar, förutsättningar för behandling och könsaspekter.

\section{Inledning}

Sedan år 1994 ansvarar Statens institutionsstyrelse, SiS, för de särskilda ungdomshemmen och de s.k. LVM-hemmen i Sverige. De särskilda ungdomshemmen är till antalet mellan 30 och 40 med cirka 700 platser (Knudsdotter Vanström et al. 2004, Faktablad från SiS 2004). ${ }^{1}$ Ungdomar kan

Ninive von Greiff är doktorand vid Institutionen för socialt arbete, Stockholms universitet placeras akut och för utredning eller för mer långsiktig behandling och majoriteten placeras med tvång.

Ett grundläggande problem för en behandlingsorganisation av den typ som Statens institutionsstyrelse utgör, består i att etablera adekvata kopplingar mellan specifik problematik hos enskilda klienter och de insatser som initieras i syfte att

1 Antalet varierar då undersökningsgruppen är utspridd över flera år. 
åtgärda denna problematik. Problemställningen är inte unik, den återfinns - mer eller mindre uttalad - inom många delar av socialtjänsten där relationen mellan problembeskrivning och interventioner ofta karakteriseras av en låg grad av institutionalisering. Det medicinska paradigmets grundläggande koppling mellan diagnos och intervention saknas i det stora hela inom socialtjänstens fält. SiS införande av ADAD (Adolescent Drug Abuse Diagnosis) som bedömningsinstrument för ungdomars problematik kan ses som ett svar på den utmaning denna frånvaro av en artikulerad koppling mellan problem och intervention innebär för socialt inriktade behandlingsinterventioner i en samtid som präglas av alltmer uttalade krav på en evidensbasering av professionella insatser. Men någon egentlig granskning av detta omfattande monitoringsystem (ca 5800 intervjuer till dags dato), vare sig när det gäller hur materialet skall tolkas eller hur det används av SiS, har ännu inte kommit till stånd.

Den typ av social problematik som utgör den primära grunden för flertalet placeringar på de särskilda ungdomshemmen är till sin natur tämligen sammansatta och svåra att innehållsmässigt avgränsa, en omständighet som ytterligare försvårar arbetet med att upprätta tydliga kopplingar mellan ungdomarnas problem och de åtgärder som sätts in. Även om brottslighet och missbruk utgör de mest centrala problemkategorierna hos de ungdomar som placeras på särskilda ungdomshem (Årsrapport ADAD 97-01) återfinns också andra konstellationer. Sarnecki (1996) har med hjälp av faktoranalys konstruerat fyra olika problemprofiler (en femte karakteriseras via frånvaron av en specifik tillhörighet). Förutom en brotts- och en missbruksprofil identifierar Sarnecki profiler som kännetecknas av psykiska och sexuella problem. Berg (2002) har använt ADAD för att studera flickors problembild genom faktoranalys och klusteranalys. Resultaten från hennes studie visar att problembilden för flickorna på särskilda ungdomshem är mycket heterogen, men en klusteranalys gav sex grupper. Av dessa hade fyra ett uttalat missbruk, men missbruket såg olika ut både vad gäller preparat och kombinationer med andra problem. I redovisningen av data från SiS framgår att hälften av alla ungdomar är placerade med hänvisning till en problembild som innefattar ett missbruk (Årsrapport ADAD 00). Någon fördjupning av hur detta missbruk är differentierat över den aktuella gruppen, eller hur missbruksfaktorn förhåller sig till andra identifierade problem eller problemområden finns emellertid ännu inte.

Syftet med föreliggande studie är att belysa hur olika bedömningar förhåller sig till varandra när det gäller beskrivning av ungdomars problembild, med särskild tonvikt på beskrivningar av missbruk och att diskutera vilken betydelse detta kan ha för $\mathrm{SiS}$ verksamhet. De fyra olika bedömningar som kommer att jämföras är socialtjänstens placeringsorsak, ungdomarnas egna problembeskrivningar och intervjuarnas (institutionspersonalen som utför ADADintervjun) skattningar av ungdomarnas behov av hjälp för olika problem samt ungdomarnas egna skattningar av oro/besvär av 
olika problem och hjälpbehov. ${ }^{2}$ Avsikten är att inom ramen för denna artikel relatera beskrivningarna till varandra och föra en diskussion kring möjligheter och svårigheter att identifiera problem och hjälpbehov. ${ }^{3}$ Studiens centrala frågeställning är hur bedömningskällorna förhåller sig till varandra avseende missbruk.

\section{Bakgrund}

\section{Lagen med särskilda bestämmelser om vård av unga}

Placering på ett särskilt ungdomshem sker efter beslut i länsrätten och föregås av en ansökan från socialnämnden. ${ }^{4}$ Nämndens ansökan ska bland annat innehålla en redogörelse för den unges förhållanden, beskrivning av problem och grunden för vård(Thunved et al. 2003, Fahlberg \& Magnusson 1991). Den lag som reglerar vård av ungdomar när föräldrar, andra vårdnadshavare eller - om den

2 Uppgiften om placeringsorsak hämtas från Klient- och institutionsadministrativa systemet (KIA), vars data bygger på de uppgifter som socialtjänsten anger i sin anmälan (på särskild blankett: Anmälan om behov av plats på särskilt ungdomshem) till SiS placeringsenhet inför en placering på särskilt ungdomshem. Uppgifterna i KIA förs sedan över till ADAD.

3 Studien saknar empiriskt material för att värdera hur dessa olika bedömningar har gått till.

4 Placering på särskilt ungdomshem kan även ske frivilligt enligt Socialtjänstlagen (SoL). Av de ungdomar som ingår i föreliggande studie är 13 procent placerade enligt SoL $\S 6$, andelen minskade när undergrupper med missbruksproblematik studerades. unge fyllt 15 år - den unge själv motsätter sig detta benämns Lag (1990:52) med särskilda bestämmelser om vård av unga ( $L V U$ ). Vård enligt LVU kan komma i fråga vid brister i omsorgen eller om något annat förhållande i hemmet medför påtaglig risk för att den unges hälsa eller utveckling skadas, s.k. miljöfall (§ 2 LVU) eller pga. eget beteende, exempelvis missbruk ( 33 LVU). Vård enligt LVU $§ 2$ får endast beredas ungdomar under 18 år medan LVU $§ 3$ kan beredas ungdomar upp till 20 år.

De s.k. beteendefallen delas in i tre problemkategorier: missbruk av beroendeframkallande medel, brottslig verksamhet och annat socialt nedbrytande beteende (LVU 1990:52 § 3). Med missbruk av beroendeframkallande medel avses alkohol, narkotika och jämförbara tekniska preparat, t.ex. tinner (Thunved et al. 2003). Lagtexten anger att ett ingripande kan ske i ett tidigt skede, för att vända en destruktiv utveckling. Enstaka bruk av tung narkotika, såsom heroin, liksom en längre tids missbruk oavsett preparat bedöms kunna innebära en påtaglig risk för att den unges hälsa eller utveckling skadas. Detta gäller även icke-medicinsk användning av läkemedel som kan medföra en hälsorisk (a.a. s. 28). Ungdomens ålder, drogens art och brukets omfattning i tid och mängd vägs in i bedömningen, men även såväl fysiska som psykiska skador orsakade av bruket. Också ungdomens sociala utveckling vägs in. Det föreligger inte krav på att hälsan och den sociala utvecklingen ska ha skadats, det räcker att den med största sannolikhet kommer att skadas om droganvändningen fortsätter (a.a.). Av lagtextens medgivande till ingripande i tidigt skede följer frågor 
dels kring kriterier för fastställande av om en människa är på väg in i ett beroende och dels definitioner av missbruk (Stenström \& Söderholm Carpelan 1996).

Med brottslig verksamhet avses varken "bagatellbrott» eller enstaka, ej allvarliga brott utan brottslighet som "...ger uttryck för en sådan bristande anpassning till samhällslivet att det kan sägas föreligga ett vård- och behandlingsbehov..." (Thunved et al. 2003 s. 28). Ungdomar som med sitt beteende avviker från samhällets grundläggande normer kan beredas vård pga. »annat socialt nedbrytande beteender. ${ }^{5}$ Det kan röra sig om enstaka allvarliga brott, att den unge vistas i olämpliga miljöer, såsom missbruksmiljö, eller att den unge prostituerar sig. Gränsen för bristande anpassning är otydlig men avgörande är ungdomars sätt att uppträda och uppföra sig (Shlytter 1999). Det räcker inte att följderna av ett beteende bryter mot samhällets normer, det är själva beteendet som ska vara asocialt (Prop 1989/90:28 s. 67).

\section{Statens institutionsstyrelse och ADAD}

SiS ansvarar för att, på socialtjänstens begäran, placera ungdomen på ett särskilt ungdomshem och institutionerna ansvarar för att vården anpassas efter den unges behov och förutsättningar. Som ett led i ökade krav på kunskapsbaserad vård och behandling inom det sociala arbetet (Söderholm Carpelan \& Hermodsson 2004, Socialstyrelsen 2000) introducerade SiS år 1997 den s.k.

5 I fortsättningen »annat».
ADAD-intervjun. Avsikten är att $\mathrm{ADAD}$ ska fungera dels som underlag för anpassning av behandling (diagnostisering av ungdomarnas problembild) och dels som redskap för uppföljning av behandlingseffekter.

Med ADAD som utgångspunkt ska personalen på särskilda ungdomshem få en uppfattning om den unges problembild för att kunna anpassa vården eller behandlingen efter de behov som framträder. Den information som utgör underlag för denna uppfattning kommer dels från de uppgifter som socialtjänsten angivit, mer precist vilken placeringsorsak som finns angiven i $\mathrm{ADAD}$, och dels ungdomarnas egna uppgifter kring de frågor som ingår i ADAD-intervjun. $\mathrm{ADAD}$ utgörs även av intervjuarens och den unges skattningar av problem och hjälpbehov. ${ }^{6}$ Det förefaller rimligt att denna bild kan förändras under institutionsvistelsen och att vården till viss del kan ändras, men den initiala och troligen till stor del styrande bilden formas som ett resultat av intervjun. Det finns därför anledning att studera hur dessa olika bedömningar förhåller sig till varandra i identifieringen av problem och hjälpbehov.

\section{Vaga begrepp och lösa kopplingar}

Länsrättens beslut grundar sig på den

6 Skillnaden mellan ungdomarnas problembeskrivningar och deras bedömningar av problem och hjälpbehov ligger i att det förra är svar på frågor om förekomst av olika problem för att få en bakgrundsbeskrivning av ungdomen. Det senare avser ett värde på en skala som anger problemets intensitet. 
utredning som socialtjänsten överlämnar. Hur denna utredning formuleras och hur den unges problem framställs ligger inte inom ramen för föreliggande studie. Däremot är socialtjänstens placeringsorsak missbruk, brott eller "annat « - av betydelse för den placering som görs och för föreliggande studie. Det saknas riktlinjer för hur dessa bedömningar mer precist ska utformas och kriterierna som finns angivna i lagtexten är i vissa fall svåra att fastställa (se Schlytter 1999). Exempelvis förefaller det svårt att klarlägga ett bruk av narkotika och ännu svårare är gränser när det gäller bruk av alkohol. Mest problematiskt förefaller fastställandet av "annat" att vara, den placeringsorsak som är mest förekommande hos flickor. Diffusa begrepp och redskap är inget unikt för institutionsvård av ungdomar. Det förefaller snarare vara genomgående när det gäller såväl problembeskrivningar som insatser inom socialtjänstens ramar (se t.ex. Sallnäs 2000 för ett exempel inom barnavårdens institutioner). Såväl mål och syfte med insatser, som identifiering av problem och definiering av behandlingsinsatser, är många gånger oklara. Bristande kunskap om vad som fungerar, men framförallt svårigheter att genomföra studier för att hitta allmänna metoder som kan anpassas individuellt, gör problemet komplext.

Formuleringar av problemkategorier tenderar att erbjuda ett begränsat antal kategorier. Samtidigt kan definitionerna uppfattas som diffusa, vilket skapar ett utrymme för egna tolkningar. Insatser med diffusa mål och syften resulterar i ett behov av att artikulera det man gör. Detta kan leda till att man tar fasta på vissa begrepp utan en gemensam överenskommelse om begrep- pens innehåll (se Sallnäs 2000 s. 196). Det måste rimligtvis vara så att såväl socialarbetare som gör utredningar om ungdomar som intervjuare som gör skattningar kan ha olika uppfattning om bedömningar av problem. Därtill kommer de juridiska bedömningarna och språkbruket. Lösa kopplingar (se Hasenfeld 1983, Scott 2003, Weick 1976) - exempelvis mellan det man säger att man gör och det man faktiskt gör - förefaller vara ett användbart begrepp för analysen av diffusa och vaga beskrivningar.

Identifiering och kategorisering av problem ligger även till grund för den vård/ behandling som ska erbjudas. Behandlingsbegreppet har diskuterats av bland andra Bergmark och Oscarsson (2000), då gällande vuxna alkoholmissbrukare. Bergmark och Oscarsson pekar på den mängd metoder som erbjuds och bristen på gemensamma nämnare och svårigheten att särskilja dessa insatser från insatser som inte är behandling. Detta indikerar att problemet med diffusa och vaga begrepp även i stor utsträckning gäller behandlingsinsatser. Sallnäs (2000) visar i sin studie av barnavårdsinstitutioner att långt ifrån samtliga institutioner har en uttalad metod eller modell för behandling. Därtill kommer förekomsten av beskrivningar som inte innehåller någon "...'vedertagen' teori/modell/metod" (a.a. s. 198). Andreassens (2003) studie av institutionsbehandling av ungdomar, en studie med syfte att göra en sammanställning av effektstudier av behandlingsinsatser, kan ses som ett led i det ökade trycket på att behandlingsmetoder ska vila på någon form av vetenskaplig grund. Problemet med vaga begrepp är dock därigenom inte nödvändigtvis löst. Tydliga ramar för behandlings- 
former gäller fortfarande i stor utsträckning benämningar snarare än dess innehåll.

Identifieringen av en klient, när det gäller ungdomar som blir föremål för institutionsvård enligt LVU, sker dels i socialtjänstens utredning och länsrättens bedömning och dels när ungdomen placeras och intervjuas av ADAD. Mot bakgrund av diskussionen ovan förefaller det relevant att studera hur olika bedömningar och framställningar förhåller sig till varandra. Kunskap saknas om hur socialtjänstens placeringsorsak, som är grunden till omhändertagandet, förhåller sig till ungdomens självrapporterade missbruk, hans/hennes uppfattning om problem och hjälpbehov samt personalens (i detta fall de som genomför ADAD-intervjun) skattning av den unges hjälpbehov. Dessa olika bedömningar kan förväntas säga något om vilken syn som präglar uppfattningar eller snarare framställningar av missbruksproblematik och huruvida dessa skiljer sig åt när man studerar olika grupper.

Det är, sammanfattningsvis, bekymmersamt när det gäller såväl problembeskrivning (diagnos) och insatser (behandling) mot sociala problem att legitimiteten sällan vilar på vetenskapligt grund. Detta har medfört mycket vaga riktlinjer när det gäller att "diagnostisera" och utrymmet är stort för olika uppfattningar och bedömningar av definierandet av ett problem och adekvat behandling av densamma.

\section{Studiens material - ADAD- intervjun}

Ursprungligen kommer ADAD från USA där det utvecklats av Friedman och Utada med ASI (Addiction Severity Index) avsedd för vuxna, som utgångspunkt (Friedman \& Utada 1989). ADAD har översatts till flera språk och används i olika versioner i flera länder (se exempelvis Bologini et al. 2001). För att kunna användas i Sverige har instrumentet översatts och anpassats till svenska förhållanden, ett arbete som har skett i samarbete med en referensgrupp bestående av behandlingspersonal från SiS institutioner (Söderholm Carpelan et al. 2000). ADADintervjun består av tre delar; en intervju som görs vid inskrivning, en som görs vid utskrivning/överflyttning och en tredje som används vid uppföljning för att kunna undersöka förändring/utveckling. Inskrivningsintervjun, som är den mest omfattande, består av ett stort antal frågor kring nio olika livsområden: fysisk hälsa, skolgång, arbete/sysselsättning, fritid och kamratkontakter, familjeförhållanden, psykisk hälsa, kriminalitet, alkohol och narkotika. Intervjun innehåller också skattningar avseende problem och behandlingsbehov både från ungdomarna och från intervjuarna. För varje frågeområde erhålls fyra centrala mått: den unges uppfattning av sina problem, den unges bedömning av sitt behov av hjälp, intervjuarens skattning av den unges behandlingsbehov och slutligen ett kompositvärde som är ett sammansatt mått som bygger på ett antal frågor som beskriver den unges situation. ${ }^{7}$ Inskrivningsinter-

7 Skattningsskalan för ungdomarna omfattar värdena: "inte alls", »lite», "ganska mycket» och "mycket». Skattningsskalan för intervjuarna omfattar värdena: "inga reella problem", »obetydliga/lätta problem", "måttliga problem", "betydande problem" och "avsevärda/utomordentligt stora problem". 
vjun, som i regel tar ca 1-1,5 timmar, görs av behandlingspersonal som fått särskild utbildning. Målsättningen är att alla ungdomar ska intervjuas. ${ }^{8}$ Om den unge kommer från en annan institution där intervju redan gjorts görs inte en ny intervju om inte den unge varit utskriven minst åtta veckor och skrivs in på nytt. Ungdomarna avgör själva om intervjun får ingå i forskningsregistret, dvs. om intervjun får användas för statistik och databearbetningar. $^{9}$

Studiens material utgörs av ADAD inskrivningsintervju åren 1997-2001. ${ }^{10}$

8 Av olika anledningar intervjuas inte alla ungdomar och bortfallet kan sägas vara betydande (mellan 30 och 36 procent de studerade åren), några av de skäl som anges är kort vistelsetid, bristande rutiner eller att den unge inte vill bli intervjuad (Årsrapport ADAD 97-01). Enligt SiS egna bedömningar är tillfälliga organisatoriska förhållanden (såsom hög personalomsättning) den vanligaste orsaken till att vissa ungdomar inte blir intervjuande. SiS har gjort begränsade bortfallsanalyser som visar att det inte finns några systematiska skillnader avseende ålder, kön, placeringar och typ av institutioner. Detta indikerar att bortfallet inte är av avgörande betydelse för tolkningar av föreliggande studies resultat. En systematik i bortfallet, avseende exempelvis problemtyngd, skulle kunna medföra ökade eller minskade skillnader i de bedömningar som studeras. Trots att inget tyder på systematik i bortfallet, finns anledning till viss försiktighet $\mathrm{i}$ tolkning av studiens resultat.

9 Åren 1997-2001 avböjde årligen mellan 34 och 71 ungdomar bearbetning av intervjun.

10 Inskrivningsintervjun har i stort sätt sett likadant ut genom åren, vissa justeringar gjordes dock inför 2000. Detta har dock inte ansetts ha några inverkningar på materialet som sådant.
Då inskrivningsintervjuer görs vid varje ny inskrivning innehöll materialet initialt fler intervjuer än individer. Alla intervjuer utöver den första för varje individ sorterades bort, av totalt 2990 vårdtillfällen återstod 2553 individer. Även de individer som omhändertagits enligt Lagen om sluten ungdomsvård (LSU) sorterades bort eftersom dessa dels inte finns representerade för alla år (lagen introducerades år 1999) och dels kan ha en annan typ av problematik och därför bör studeras separat. 2452 individer återstod efter denna sortering, av dessa är 1683 män (69 procent) och 769 kvinnor (31 procent).

\section{Självrapporterade uppgifter}

Ett vanligt problem när det gäller självrapporterad konsumtion av alkohol och droger är att den tenderar att vara lägre än den faktiska konsumtionen (Kühlhorn et al. 2000). ${ }^{11}$ Enligt ADAD årsrapporter 97-01 har intervjuarna uppskattat andelen förvanskade svar på missbruksfrågorna till i genomsnitt knappt tio procent och det antas att ungdomar som omhändertas omedelbart (i väntan på beslut i länsrätten) kan tänkas anpassa sina svar för att undvika ett omhändertagande(Årsrapport

\footnotetext{
11 I boken Alkoholkonsumtionen i Sverige under 1990-talet presenteras en utförlig diskussion kring olika skalors för och nackdelar när det gäller mätning av alkoholkonsumtion. Författarna menar att det finns en risk för underrapportering i frågor som gäller "normalvecka", vilket i ADAD kan översättas till "typisk månad».
} 
ADAD 01) ${ }^{12}$ Det finns även en risk för det omvända - att vissa ungdomar överdriver konsumtion av narkotika av olika orsaker (exempelvis att de vill utmana personalen). Vetskapen om problem med denna typ av data innebär dock inte att den inte kan användas. Trots riskerna för över- såväl som underrapporterad konsumtion är det dessa uppgifter intervjuarna (behandlingspersonalen) har att utgå ifrån. Genom att även använda ungdomarnas egna bedömningar av problem och hjälpbehov är förhoppningen att ge studien ytterligare en viktig dimension.

\section{Redovisning av resultat}

Med utgångspunkt i fyra olika bedömningar, se figur 1 nedan, diskuteras i det följande olika sätt att beskriva ungdomarnas problem och hur dessa beskrivningar förhåller sig till varandra. Det bör understrykas att bedömningarna görs av olika perso-

12 Det finns, enligt SiS, inget som tyder på systematisk förvanskning av uppgifter. En närmare granskning av ett urval frågor i avsnitten om alkohol och narkotika visar att resultaten inte ändras när uppgifter som skulle kunna vara osäkra utesluts (Årsrapport ADAD 01 s. 9). ner i olika situationer med olika underlag för bedömningar och med olika avsikter för vad bedömningarna ska leda till. De jämförelser som görs i studien använder materialet på ett sätt som inte är dess primära avsikt och tar ingen hänsyn till andra bedömningar som eventuellt har betydelse. Avsikten är inte att ge en nyanserad bild av hur bedömningarna har gått till, något som hade krävt ett annat empiriskt material. Inte heller vet vi något om hur bedömningarna ser ut på individnivå. Avsikten är istället att på aggregerad nivå jämföra de olika bedömningar som finns att tillgå via $\mathrm{ADAD}$ och därmed indirekt frilägga ett antal interna motsättningar som återfinns inom den databas SiS har byggt upp med hjälp av ADAD.

\section{Placeringsorsak enligt socialtjänsten}

Socialtjänstens placeringsorsak sammanfattas i kategorierna: "missbruk", "brott", "annat" och kombinationer av dessa. Under de fem studerade åren hade 1170 ungdomar placerats helt eller delvis pga. missbruk: 289 ungdomar hade placerats pga. »enbart missbruk", 325 för "missbruk + brott», 281 för "missbruk + annat» och 274 för kom-

\section{Figurl.}

Ett till fyra anger de bedömningar av ungdomars missbruk som jämförs $i$ studien, samtliga hämtade från $A D A D$.

1.

Placeringsorsak enligt socialtjänsten

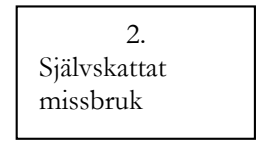

4.

Intervjuarnas skattningar

Ninive von Greiff: Missbruk bland ungdomar på särskilda ungdomshem - ADAD som ... 
bination av alla tre problemkategorier (se figur 2). Jämförelser mellan könen i gruppen med missbruk som placeringsorsak ger vissa skillnader: pojkarna är överrepresenterade $\mathbf{i}$ "missbruk + brott" medan hälften av flickorna har placerats pga. "missbruk + annatu. ${ }^{13}$ Omkring en fjärdedel av pojkarna och flickorna i den studerade gruppen är placerade pga. »enbart missbruk» (ej i figur).

Omfattningen av missbruk har studerats för dem som placerats pga. sitt missbruk ( $\mathrm{N}=1170)$ jämfört med övriga $(\mathrm{N}=1282)$, även skillnader i missbruk inom gruppen med missbruk som placeringsorsak har undersökts. Ungdomar som har placerats pga. sitt missbruk skiljer sig åt från de övriga på samtliga narkotiska preparat, där den förra gruppen har fler som ofta använder narkotika och den senare fler som aldrig gör det. ${ }^{14}$ Bruk av narkotika förekommer dock även bland dem som inte placerats pga. missbruk. Jämförelser inom gruppen med missbruk som placeringsorsak visade på signifikanta skillnader för samtliga preparat. I gruppen av ungdomar med placeringsorsak "enbart missbruk" fanns en högre andel som ofta använde olika narkotiska preparat. Grupperna «missbruk + annat" samt kombinationen av samtliga placeringsorsaker hade högst andelar som aldrig använt narkotika (samtliga preparat).

Frågor i $\mathrm{ADAD}$ kring självrapporterat

13 Test med Chi-2 visar på signifikanta skillnader.

14 Avser frågan om användning av åtta narkotiska preparat en "typisk månad" med värdena aldrig, sällan, ganska ofta och ofta (för diskussion kring val av variabel se avsnittet om missbruk enligt ADAD). Test med Chi-2. missbruk av narkotika, och till viss del även alkohol, har använts för att få en uppfattning om socialtjänstens placeringsorsak även framträder i ungdomarnas självrapporterade missbruk av narkotika. Frågorna har även använts för att se i vilken utsträckning missbruk förekommer $i$ andra grupper än de som placerats pga. missbruk. Missbruket, så som det framkommer i ADAD, presenteras nedan följt av en återkoppling till socialtjänstens placeringsorsak.

\section{Placeringsorsak missbruk - obefintlig eller marginellt självskattat bruk.}

Av samtliga som har missbruk som placeringsorsak $(\mathrm{N}=1170)$ har 398 ungdomar svarat att de sällan ( 1 gång/månad) eller aldrig använder något narkotiskt preparat. Bland dessa 398 ungdomar använder drygt en femtedel alkohol ofta, dvs. 2-3 ggr/vecka eller mer, knappt en tredjedel använder alkohol 2-4 ggr i månaden, drygt en tredjedel använder alkohol sällan och tio procent använder aldrig alkohol. Resultaten överensstämmer med den totala missbruksgruppen och sett till hela populationen ( $\mathrm{N}=2452)$ är det något högre andel "högkonsumenteru. Utan tillgång till utredning och dom är det inte möjligt att svara på vad hos dessa ungdomar som gjort att de placeras pga. missbruk. Det kan vara ungdomar som förvanskat sina uppgifter, som i en helhetsbedömning från socialtjänsten - baserat på exempelvis ålder och brukets omfattning i tid och mängd (se § 3 LVU) ansetts ha problem med missbruk - men det kan också vara exempel på fall där 
placeringsorsaken inte är den mest adekvata. Könsfördelningen är densamma som i materialet i stort, dvs. ungefär en tredjedel flickor och två tredjedelar pojkar. Placeringsorsaken för dessa 398 ungdomar var 16 procent "enbart missbruk«, 27 procent "missbruk + brott", 30 procent "missbruk + annat" och 27 procent "missbruk + brott + annat». Intervjuarnas skattningar och ungdomarnas egna bedömningar, för de 398, av problem och hjälpbehov avseende missbruk av narkotika ligger betydligt lägre än övriga studerade "missbruksgrupper" (se nedan). Detta pekar på att det för dessa ungdomar är andra problem än narkotika som påverkat omhändertagandet, trots placeringsorsak. Vilka dessa problem är och hur dessa värderas i relation till missbruk förefaller meningsfullt att studera, detta kan dock inte göras inom ramen för denna studie.

\section{Missbruk enligt ADAD}

Hur ser då konsumtion av narkotika ut för de ungdomar som intervjuas med ADAD? Utgår man från socialtjänstens placeringsorsak utgör det ett annat problem att bruk av narkotika även förekommer i grupper med andra orsaker till placering, samtidigt som missbruket bland dem som placerats pga. missbruk kan se olika ut och variera i omfattning. För att få en mer nyanserad bild har även ungdomarnas självrapporterade konsumtion använts för att jämföra med socialtjänstens placeringsorsak och intervjuarnas skattningar samt med ungdomarnas egna uppfattning av sina problem och hjälpbehov.

För att dela in ungdomarna i grupper baserade på deras bruk av narkotiska preparat har frågor om användning under en typisk månad använts. I ADAD finns även uppgifter om användning de senaste 30 dagarna, ålder vid det första missbrukstillfället och när man senast använde ett preparat. Valet av "typisk månad" gjordes mot bakgrund av att en betydande andel av ungdomarna befunnit sig på institution tiden innan intervjun och därför kan antas haft begränsad möjlighet att använda alkohol och narkotika, åtminstone i den utsträckning som de brukar. Konsumtionsfrekvenserna av preparaten kodades till »aldrig", "sällan", "ganska ofta» och »ofta» och för att sortera ut ungdomar med missbruksproblematik användes olika kombinationer av omfattning av olika preparat. ${ }^{15}$ Utifrån ungdomarnas egna bedömningar använde 773 ungdomar ganska ofta eller ofta något av åtta narkotiska preparat, 605 av dessa använde något preparat ofta. ${ }^{16} 364$ ungdomar använde amfetamin (injicerat och/eller oralt) och/ eller heroin (injicerat och/eller oralt) ganska ofta eller ofta, 125 av dessa ungdomar injicerade amfetamin och/eller heroin ganska ofta eller ofta. ${ }^{17}$ I fortsatta redovisningar

15 Sällan = 1 gång i veckan eller inte angiven månad, ganska ofta = 2-4 ggr i månaden och ofta $=2-3$ ggr i veckan eller mer.

16 Marijuana, amfetamin (oralt/injicerat), heroin (oralt/injicerat), kokain, LSD, ecstasy. Det handlar i realiteten om sex preparat men en uppdelning har gjorts mellan oralt intag och injicerat.

17 Amfetamin och heroin är preparat som brukar karakteriseras som mer allvarliga och förknippas med mer allvarligt missbruk jämfört med exempelvis ecstasy som inte är lika stigmatiserande. 
fokuseras på de 773 (se figur 2) ungdomar som använde minst ett preparat minst 2-4 ggr i månaden. Valet är gjort för att de enligt den självrapporterade konsumtionen har ett missbruk, med utgångspunkt från den, om än diffusa, definition som anges i bland annat LVU (se Thunved 2003 s. 28, SOSFS 1997:15 s. 31). Fortsättningsvis benämns gruppen som den självskattade missbruksgruppen. Könsfördelningen i den självskattade missbruksgruppen är densamma som i övriga materialet (ca en tredjedel flickor och två tredjedelar pojkar). Även när det gäller placeringarnas lagrum överensstämde gruppen med populationen $\mathrm{i}$ övrigt.

\section{Hurser alkoholkonsumtionen ut i den självskattade missbruksgruppen?}

Bland ungdomarna i den självskattade missbruksgruppen uppger fem procent att de aldrig konsumerar alkohol, drygt en tredjedel att de gör det sällan (36 \%) och 58 procent konsumerar alkohol 2-4 ggr i månaden eller mer. ${ }^{18}$ Detta kan jämföras med den totala populationen av placerade ungdomar de undersökta åren ( $\mathrm{N}=2452)$ där 14 procent aldrig konsumerar alkohol, 40 procent gör det sällan och 46 procent ganska ofta eller ofta konsumerar alkohol. Andelen "högkonsumenter" (dvs. de ungdomar som dricker alkohol 2-3 ggr i veckan eller mer) är 18 procent i hela populationen och 32 procent i den självskattade missbruksgrup-

18 För att mäta alkoholkonsumtionen har variabeln »typisk månad» använts (se not 15). pen. Resultaten kan jämföras med data från CAN (Centralförbundet för alkohol- och narkotikaupplysning) som visar att bland svenska ungdomar i åldern 16-18 år uppger 13 procent att de aldrig konsumerar alkohol, drygt hälften (53\%) att de gör det 1 gång/ månad eller mer, knappt en tredjedel (30\%) 2-4 ggr i månaden och 4 procent uppger att de konsumerar alkohol 2-3 ggr i veckan eller oftare (Guttmorsson et al. 2004).

\section{Ej missbruk som placeringsorsak}

Bland de 773 ungdomar som ganska ofta eller ofta använder något narkotiskt preparat har 111 inte placerats pga. sitt missbruk - 82 pojkar och 29 flickor. För att undersöka om dessa 111 ungdomar skiljer sig från övriga 662 vad gäller bakgrundsvariabler och olika problemområden gjordes korstabeller och chi-2 test. Grupperna skiljer sig inte när det gäller omfattande alkoholkonsumtion (2-3 ggr i veckan eller mer) men när det gäller narkotika använde andelen som hade missbruk som placeringsorsak narkotiska preparat i högre utsträckning, skillnaden var signifikant för samtliga åtta undersökta preparat.

Könsfördelningen i grupperna (111 jämfört med 662) skilde sig inte åt, däremot var gruppen som inte placerats pga. missbruk yngre än de som hade missbruk som placeringsorsak, sett till den grupperade åldersfördelningen. När det gäller problemområden kan nämnas att avseende brottslighet de senaste tre månaderna var skillnaderna mellan de 111 som inte placerats pga. missbruk och övriga 662 signifikanta för flerta- 
let brottstyper. Bland ungdomar placerade pga. sitt missbruk var andelarna som begått narkotikabrott och rattonykterhet högre medan de 111 som inte placerats pga. sitt missbruk hade högre andelar på förargelseväckande beteende, skadegörelse, rån, hot/ våld mot tjänsteman och misshandel.

\section{Ungdomarnas bedömningar av problem och hjälpbehov samt intervjuarnas skattningar}

Ungdomarna gör i slutet av varje frågeområde en bedömning av sina problem (oro/ besvär senaste 30 dagarna) och hjälpbehov på en fyrgradig skala från "inte alls", »lite» och "ganska mycket" till "mycket». ${ }^{19}$ Även intervjuaren gör en skattning av ungdomens hjälpbehov på en niogradig skala, en skala som i realiteten motsvarar fem steg: »inga reella problem, behöver inte ytterligare hjälp" (0-1), »obetydliga problem, ytterligare hjälp troligen inte nödvändigu (2-3), "måttliga problem, viss hjälp önskvärd» (45), "betydande problem, hjälp nödvändig" (6-7), »avsevärda/utomordentligt stora problem, hjälp är absolut nödvändig" (8-9). ${ }^{20}$

19 För jämförelser med intervjuarna har variabeln kodats om så att inte alls och lite $=0$ och ganska mycket och mycket $=1$.

20 Variabeln kodades om till inga/måttliga problem (0-5) och betydande/avsevärda (6-9) för att särskilja de som bedömdes vara i störst behov av hjälp.

\section{Figur 2.}

Olika grupperingar av materialet med utgångspunkt $i$ socialtjänstens placeringsorsak och ungdomarnas självrapporterade uppgifter.
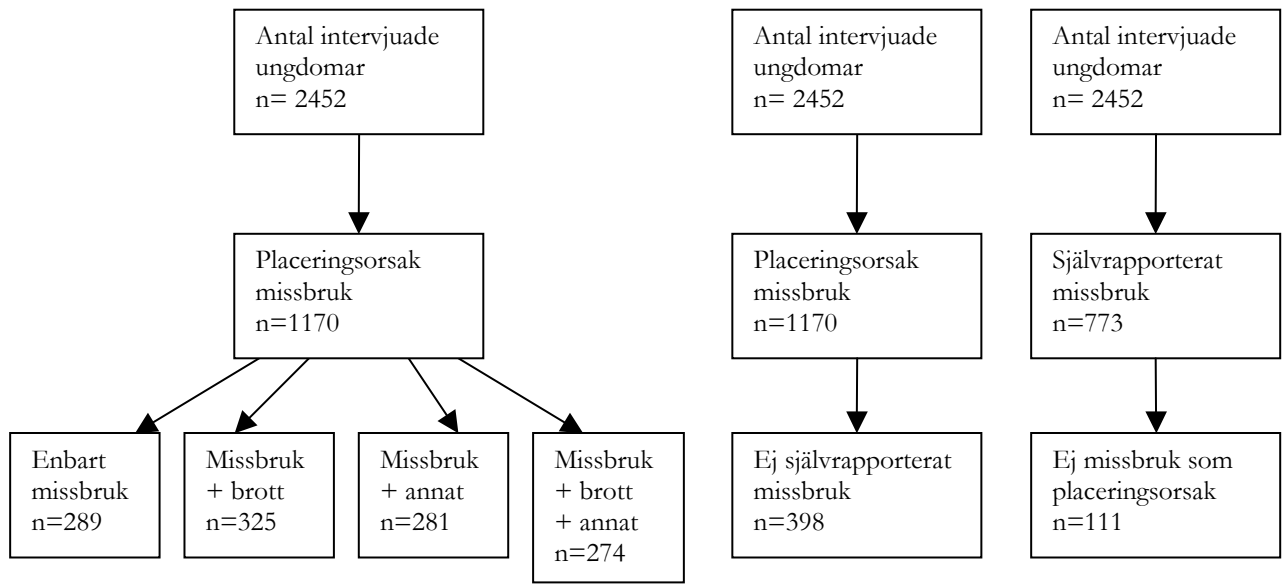

Ninive von Greiff: Missbruk bland ungdomar på särskilda ungdomshem - ADAD som ... 


\section{Skillnader och likheter mellan intervjuarnas skattningar och ungdomarnas bedömningar av olika problem. ${ }^{21}$}

Jämförelser mellan intervjuarens skattning och ungdomens bedömningar av problem och hjälpbehov visade signifikanta skillnader för samtliga åtta undersökta problemområden, se Tabell 1 första kolumnen, nedan. Detta indikerar att det finns betydande skillnader mellan hur ungdomarna själva uppfattar sina problem och hur intervjuaren gör det. För att undersöka eventuella skillnader mellan intervjuarnas och ungdomarnas uppfattning om på vilka områden hjälpbehovet bedöms vara störst (6-7 enligt ovan) gjordes korstabeller och signifikanstest med chi-2.22 Skillnaderna var signifikanta för alla problemområden. De områden där intervjuarna skattat hjälpbehovet högst är narkotikaproblem, brottsligt beteende och fritid/vänner (i nämnd ordning). Ungdomarnas bedömningar av hjälpbehov ligger i allmänhet lägre men hjälpbehoven anses störst gällande skolproblem, narkotikaproblem, familjeproblem och arbete. En uppdelning på kön visar

21 Det faktum att ungdomarna ombeds göra "bedömningar" och intervjuarna "skattningar" samt att de har olika skalsteg att ta hänsyn till kan försvåra tolkningen av jämförelserna. Här är avsikten dock enbart att peka på tendenser i materialet och för detta ändamål förefaller jämförelser genomförbara.

22 Avser de 773 som svarat att de ganska ofta eller ofta använder minst ett av åtta undersökta narkotiska preparat. att intervjuarnas skattningar av flickornas hjälpbehov, till skillnad från pojkarna vars problem bedömdes i samma ordning som för den totala gruppen, var högst för narkotika, följt av fritid/vänner och familjeproblem (tätt följt av psykisk hälsa).

Skillnaderna mellan intervjuarnas och ungdomarnas skattningar var störst för brott, narkotika och fritid/vänner. För pojkarna var skillnaden störst för samma problem, i nämnd ordning medan skillnaderna för flickorna var störst för narkotika, följt av fritid/vänner och brott. I stor utsträckning ligger intervjuarnas skattningar högre än ungdomarnas bedömningar men det finns några undantag. Ungdomarna bedömer problem med fysisk hälsa och arbete högre än intervjuarna. Om skillnaderna genomgående hade varit i riktningen att intervjuarnas skattningar låg högre skulle detta kunna förklaras med att ungdomarna själva förnekar eller inte uppfattar sina problem som så allvarliga. När skillnaderna går i olika riktningar är andra förklaringar nödvändiga. Det skulle kunna vara en indikation på att ungdomarnas upplevda problem och hjälpbehov ligger inom andra områden än det som de placerats för, något som kan vara av stor vikt för motivation till behandling. I Tabell 1, tredje kolumnen, presenteras jämförelser mellan hur pojkar och flickor själva bedömer sina hjälpbehov inom olika områden. Större andelar av flickorna bedömer sina hjälpbehov som stora, för samtliga problem förutom arbete, brott och alkohol (marginell skillnad). Skillnaderna mellan könen var signifikanta för fysisk hälsa, skolproblem, familjeproblem, psykisk hälsa och brottslighet. Liknande analyser gjordes även för den ursprungliga missbruksgrup- 
pen $(\mathrm{n}=1170)$, vilka överensstämde med resultaten från analyser av den självskattade missbruksgruppen som redovisats i Tabell 1.

\section{Sammanfattande diskussion}

Centralt för föreliggande studie har varit att lyfta fram olika instansers avgränsningar och beskrivningar av ungdomarnas problem, med särskild utgångspunkt i missbruksproblem. Materialet utgörs av data från den s.k. ADAD-intervjun som innehåller uppgifter om socialtjänstens placeringsorsak (som ligger till grund för själva omhändertagandet), ungdomarnas självrapporterade uppgifter, ungdomarnas bedömningar av problem och hjälpbehov samt intervjuarnas skattningar av densamma. Bedömningar av missbruk har lyfts fram och jämförts. Resultaten visar att bedömningar av såväl omfattning av missbruk som hur detta (miss)bruk uppfattas skiljer sig åt dels med utgångspunkt i socialtjänstens placeringsorsak och ungdomars självrapporterade uppgifter och dels i ungdomarnas respektive intervjuarnas skattningar av missbruk, såsom de framkommer i ADAD.

Skillnaderna torde hänga samman med den mer övergripande problematiken kring beskrivningar och definitioner av sociala

\section{Tabell I.}

Jämförelser mellan intervjuarnas skattningar och ungdomarnas bedömningar av hjälpbehov, intervjuarnas skattningar fördelat på kön samt ungdomarnas bedömningar fördelat på kön. Test med chi-2. Andelar i procent. $N=773$

\begin{tabular}{|c|c|c|c|c|c|c|c|c|c|}
\hline \multirow[t]{2}{*}{ Problemområde } & \multicolumn{3}{|c|}{$\begin{array}{c}\text { Skillnader mellan } \\
\text { intervjuarnas (I) } \\
\text { skattningar och } \\
\text { ungdomarnas (U) } \\
\text { bedömningar av stort } \\
\text { hjälpbehov }\end{array}$} & \multicolumn{3}{|c|}{$\begin{array}{c}\text { Intervjuarnas skattningar } \\
\text { av ungdomarnas hjälp- } \\
\text { behov } \\
\text { (betydande }=6-9 \text { ) }\end{array}$} & \multicolumn{3}{|c|}{$\begin{array}{l}\text { Ungdomarnas bedömnin- } \\
\text { gar av hjälpbehov } \\
\text { (ganska/mycket viktigt) }\end{array}$} \\
\hline & $\mathbf{I}$ & $\mathbf{u}$ & sign. & Pojkar & Flickor & sign. & Pojkar & Flickor & sign. \\
\hline Fysisk hälsa & 5 & 25 & ***** & 4 & 7 & n.s. & 22 & 31 & *** \\
\hline Skolproblem & 43 & 43 & ***** & 42 & 47 & n.s. & 40 & 52 & *** \\
\hline Fritid/vänner & 58 & 27 & ***** & 56 & 61 & n.s. & 26 & 30 & n.s. \\
\hline Arbete & 15 & 29 & ***** & 16 & 13 & n.s. & 31 & 26 & n.s. \\
\hline Familjeproblem & 45 & 33 & **** & 40 & 56 & **** & 29 & 40 & *** \\
\hline Psykisk hälsa & 41 & 28 & ***** & 36 & 54 & **** & 23 & 40 & **** \\
\hline Brottsligt beteende & 60 & 24 & ***** & 67 & 42 & $* * *$ & 29 & 13 & **** \\
\hline Alkoholproblem & 28 & 7 & ****** & 27 & 29 & n.s. & 8 & 6 & n.s. \\
\hline Narkotikaproblem & 76 & 44 & **** & 74 & 80 & n.s. & 42 & 46 & n.s. \\
\hline
\end{tabular}

${ }^{* * *}=0,001,{ }^{* *}=0,01,{ }^{*}=0,05$ 
problem. Vad som uppfattas som problem är relaterat till synen på asocialitet och när det saknas en vetenskapligt grundad kunskapsbas om hur bedömningsgrunderna ska se ut, öppnas möjligheter för subjektiva och normativa bedömningar. En, om än outtalad, avsikt med ADAD är att skapa ett gemensamt språk bland behandlingspersonal (jfr Mäkeläs diskussion kring ASI, Mäkelä 2004) och mellan socialtjänst, domstol och institutionerna. Genom att utforma ett instrument för problembeskrivning och underlag för behandling tydliggörs vilka aspekter som anses viktiga i att ringa in problem, men även vad som är att uppfatta som problem. Samtidigt som instrumentet är ett sätt att säkerställa en gemensam grund och undvika subjektiva, icke kvalificerade bedömningar finns risk att det generella sker på bekostnad av det individuella. Generella och klassificerande instrument innebär en förenkling (se Kirk 2003) och kan inte göra anspråk på att vara heltäckande, medan helt individuella bedömningar riskerar att vara subjektiva. Utan att värdera denna typ av instrument kan konstateras att det finns problem med att formulera klara riktlinjer på dessa områden som till sin natur är diffusa, samtidigt som även sociala problem måste bedömas utifrån en mer kunskapsbaserad grund. Istället, menar Kirk, bör målet med behandlingen styra snarare än klientens problem (a.a.s.142).

Avsikterna med ADAD - att skapa ett underlag för behandling och få ungdomen mer engagerad i densamma - är beaktansvärda, men frågan är vilken tyngd resultaten från $\mathrm{ADAD}$ får när ungdomen redan har kommit till en institution, vars möjlig- heter att anpassa vården individuellt kan vara begränsade pga. exempelvis specialisering och inriktning. För det stora antalet ungdomar som omhändertas omedelbart är möjligheterna större, men i vilken utsträckning ungdomar byter institution efter att ha intervjuats vet vi inte. ${ }^{23}$ Socialtjänstens placeringsorsak kan, mot bakgrund av detta, ha en stor inverkan på den behandling som ungdomarna erbjuds, trots begränsningar i möjlighet att göra adekvata bedömningar. Ungdomar som placeras en längre tid kommer troligtvis att ges möjlighet att uttrycka sina individuella behov under institutionsvistelsen. Som placeringsunderlag, tillsammans med socialtjänstens bedömning, förefaller ungdomens möjligheter dock begränsade. Det faktum att ungdomarna redan är placerade och har kommit till en institution när de intervjuas begränsar möjligheterna att göra "nya» bedömningar. Föreliggande studie har visat att relationen mellan socialtjänstens bedömning och det som framkommer i ADAD - självrapporterade uppgifter samt bedömningar - skiljer sig åt när det gäller missbruk som problem. Hur sådana skillnader hanteras och hur de olika bedömningarna värderas förtjänar en fördjupad undersökning.

Ungdomarnas bedömningar av sina problem kan tänkas påverka förutsättningarna för motivation hos ungdomarna att genomgå behandling. Det är inte bara relevant att lyfta fram det faktum att skattning-

23 Enligt SiS förekommer byten av institution. Att samköra ADAD och KIA för att få uppgifter om institutionsbyte på individnivå har inte varit möjligt inom ramen för föreliggande studie, men avses redovisas i en kommande studie. 
arna skiljer sig åt utan även på vilka områden och huruvida detta är ett uttryck för att andra problem måste lösas/behandlas innan de problem som socialtjänst, domstol och SiS lyfter fram kan komma ifråga. Bland de ungdomar som särskilt studerats i föreliggande studie visade det sig finnas skillnader mellan intervjuarnas och ungdomarnas skattningar avseende var hjälpbehovet är som störst. Skillnaderna mellan könen var inte signifikant men flickor tenderade att skattas ha mer allvarliga problem med narkotika både enligt deras egna och intervjuarnas bedömningar. Motivationsarbete och hänsyn till ungdomarnas egen problemperception torde vara viktiga aspekter för att skapa förutsättningar för goda behandlingseffekter och mer fokus på vad som ska ske i framtiden, snarare än vad som skett i det förgångna bör kanske på ett tydligare sätt ingå i ADAD. Samtidigt sker detta arbete inom ett område där bristen på kunskap om problembeskrivning och problemhantering fortfarande är stora, vilket kan medföra att de gemensamma begreppen hålls vaga och vida. Detta kan resultera i ett utrymme för individuella definitioner, vilket riskerar att utarma begreppen. Det tycks föreligga s.k. lösa kopplingar (se exempelvis Hasenfeld 1983) mellan vad som sägs/skrivs (artikuleras) och det som i realiteten menas/görs.

Sammanfattningsvis visar studien att det finns betydande skillnader mellan bedömningar av förekomst och omfattning av missbruk och vilka ungdomar som anses ha problem med missbruk, beroende på vilka uppgifter som används. Detta har relaterats till en diskussion kring problemkategorier och problembeskrivningar men också till förutsättningar för behandlingsinsatser. Möjligheterna att använda ADAD för differentiering av behandlingsinsatser har diskuterats i relation till att ungdomarna redan placerats på en institution när de intervjuas. Resultaten pekar på vissa könsskillnader, något överraskande blev könsfördelningen jämnare ju allvarligare missbruk ungdomarna själva rapporterade. Andelen flickor som injicerade ofta var lika stor som andelen pojkar. Många obesvarade frågor kvarstår. En av dessa är hur kopplingen mellan problembeskrivningar (bedömningar av problem) och vård/behandling ser ut avseende ungdomar med missbruksproblematik. Detta är ämnet för en planerad uppföljande artikel.

\section{Referenser}

Andreassen, Tore (2003) Institutionsbehandling av ungdomar. Vad säger forskningen? Stockholm: Elanders Gotab.

Berg, Marie-Louise (2002) Problemsyndrom hos flickor på särskilda ungdomshem. SiS-rapport 2002:2.

Bergmark, Anders \& Oscarsson, Lars (2000) „Om behandlingsbegreppet inom alkoholvården". I Mats Berglund (red.) Behandling av alkohol- problem - En kunskapsöversikt. Centrum för utvärdering av socialt arbete (CUS). Stockholm: Liber.

Bologini Monique, Plancherel Bernard, Laget Jacques, Chinet Léonie, Rossier Valérie, Cascone Pablo, Stéphan Philippe \& Halfon Olivier (2001) "Evaluation of the Adolescent Drug Abuse Diagnosis instrument». Addiction 96 (10) s. 1477-1484. 
Fahlberg, Gunnar \& Magnusson, Nils (1991) Socialtjänstlagarna - bakgrund och tillämpning. Borås: Almqvist \& Wiksell.

Faktablad från SiS (2004) Institutionsplaceringar $i$ Sverige år 2003 (http://www.stat-inst.se/document/Fakta_institutionsplaceringar0.pdf).

Friedman, Alfred S. \& Utada, Arlene (1989) "A method for diagnosing and planning the treatment of adolescent drug abusers" (The adolescent drug abuse diagnosis (ADAD) instrument). Journal of Drug Education, vol. 19 (4) s. 285-312.

Guttmorsson Ulf, Andersson Barbro \& Hibell, Björn (2004) Ungdomars drogvanor 1994-2003. Intervjuer med 16-24-åringar. Rapport nr 75. Stockholm: CAN.

Hasenfeld, Yeheskel (1983) Human Service Organizations. London: Prentice-Hall.

Kirk, Stuart A. (2003) »The Role of Diagnostic and Problem Classification in Formulation TargetBased Practice Guidelines». I Aaron Rosen \& Enola K. Proctor (eds.) Developing practice guidelines for social work intervention. Issues, methods and research agenda. New York: Columbia University Press.

Knudsdotter Vanström Linda, Palmgren Langlet Ann-Christine \& Björk Stina (2004) SiS statistik år 2003, Allmän SiS-rapport 2004:6.

Külhorn Eckart, Hibell Björn, Larsson Stig, Ramstedt Mats \& Zetterberg Hans L. (2000) Alkoholkonsumtionen $i$ Sverige under 1990-talet. Stockholm: Elanders Gotab.

Mäkelä, Klaus (2004) "Studies of the reliability and validity of the Addiction Severity Index". Addiction 99 s. 398-410.

Prop 1989/90:28 Regeringens proposition om vård $i$ vissa fall av barn och ungdomar.

Sallnäs, Marie (2000) Barnavårdens institutioner - framväxt, ideologi och struktur. Akademisk avhandling, Stockholms universitet, Institutionen för socialt arbete. Edsbruk: Akademitryck AB.

Sarnecki, Jerzy (1996) „Problemprofiler hos ungdomar på särskilda ungdomshem i Stockholms län åren 1990-1994«. I Bengt-Åke Armelius (red.) Vard av ungdomar med sociala problem - en forskningsöversikt. Falköping: Statens institutionsstyrelse och Liber Utbildning AB.

Schlytter, Astrid (1999) Kön och juridik $i$ socialt arbete. Tillämpningen av $3 \S L V U$ på länsrättsnivå. Lund: Studentlitteratur.

Scott, W. Richard (2003) Organizations. Rational, Natural, and Open Systems. Fifth Edition. New Jersey: Prentice Hall.

Socialstyrelsen (2000) Nationellt stöd för kunskapsutvecklingen inom socialtjänsten. SoS-rapport 2000:12 (www.sos.se/FULLTEXT/0003012/0003-012.pdf).

Stenström, Nils \& Söderholm Carpelan, Kerstin (1996) „Vård och behandling av alkohol- och narkotikamissbrukare». I Bengt-Åke Armelius (red.) Vard av ungdomar med sociala problem - en forskningsöversikt. Falköping: Statens institutionsstyrelse och Liber Utbildning AB.

Söderholm Carpelan, Kerstin \& Hermodsson, Anne (2004) "ADAD och utvecklingen av ett dokumentationssystem för ungdomar". Nordisk Sosialt Arbeid. vol. 24(2) s. 110-123.

Söderholm Carpelan Kerstin, Hermodsson Anne \& Öberg David (2000) Manual. ADAD-intervju. Reviderad version, ursprungligen tryckt 1997. Stockholm: Statens institutionsstyrelse.

Thunved Anders, Clevesköld Lars \& Thunved Birgit (2003) Samhället och de unga lagöverträdarna. Andra upplagan. Stockholm: Norsteds Juridk AB (Elanders Gotab).

Weick, Karl, E. (1976) „Educational Organizations as Loosely Coupled Systems". Administrative Science Quarterly, March (21) s. 1-19.

Årsrapport ADAD 97 (2000) Ungdomar som skrivits in på särskilda ungdomshem under 1997 - bakgrund, livssituation och behandlingsbehov. SiS följer upp och utvecklar 1/00.

Årsrapport ADAD 98 (2001) Ungdomar som skrivits in på särskilda ungdomshem under 1998 - bakgrund, livssituation och behandlingsbehov. SiS följer upp och utvecklar 1/01.

Årsrapport ADAD 99 (2002) Nyinskrivna ungdomar på särskilda ungdomshem under 1999 - bakgrund, livssituation och behandlingsbehov. SiS följer upp och utvecklar 1/02.

Årsrapport ADAD 00 (2003) Ungdomar som skri- 
vits in på särskilda ungdomshem 2000 - bakgrund, livssituation och behandlingsbehov. SiS följer upp och utvecklar 5/03.
Årsrapport ADAD 01 (2004) Ungdomar som skrivits in på särskilda ungdomshem under 2001. Tabeller. Allmän SiS-rapport 2004:3.

\section{Summary}

\section{Addiction among young persons in special approved homes: ADAD as a tool for judgement and treatment}

In Sweden young persons with grave psychosocial problems are cared for under LVU (The Care of Young Persons Act) and the inmates are placed at special approved homes (institutions) that SiS (The National Board of Institutional Care) is responsible for. In 1997 ADAD (Adolescent Drug Abuse Diagnosis) was introduced as a tool to investigate and judge clients to provide adequate treatment and also to evaluate and measure effects of treatment. The aim of this study is to compare different judgements of drug abuse among young people in special approved homes and to discuss difficulties in describing problems (diagnosing) and implications for treatment. Data were collected from ADAD from the years 1997-2001. Information from the social services about reasons for placing the young people, with special interest in those who are placed for drug abuse, are compared with the young persons' own estimation of their drug consumption, how they understand their abuse and their need of help and how the personnel at SiS, who conduct the ADAD interview, estimate the young people's need of help.

The results show considerable differences in judgements of drug abuse. According to the social services, about half of the young people in the special approved homes have problems with drug abuse. Among these about a third have estimated their use of drugs as non-existent or highly marginal. At the same time we found young people that have reported severe drug abuse who are placed in an institution for other reasons. Comparisons between the young people and the interviewers show, not surprisingly that the young people did not estimate their need of help for drug abuse as high as the interviewer. However, other problems were estimated as more important to require help with by the young people than by the interviewers, such as physical problems. Differences in problem descriptions between the sexes as well as differences in judgements of abuse are discussed in relation to conditions for treatment. 